\title{
Stereotypes and Prejudice
}

\author{
Their Overt and Subtle Influence in the Classroom
}

\author{
CONNIE T. WOLFE \\ University of Michigan \\ STEVEN J. SPENCER \\ Hope College
}

\begin{abstract}
The authors examine overt and subtle forms of stereotyping and prejudice. Two theories that explain overt prejudice are reviewed: realistic conflict theory and social identity theory. Although overt prejudice seems to have declined, subtle stereotyping is still pervasive. The authors review one theory, aversive racism theory, that explains this phenomenon. They also discuss two perspectives, attributional ambiguity and stereotype threat, which provide accounts of the impact of subtle racism. Both overt and subtle prejudice present challenges for the classroom. The authors describe one intervention called the jigsaw classroom that encourages work toward common goals and helps reduce the expression and impact of overt discrimination. A second intervention program, wise schooling, is presented, which aims to reduce the impact of subtle stereotypes by reducing stereotype threat.
\end{abstract}

Why do prejudice and discrimination exist? Has overt racism been replaced by more subtle forms of prejudice? How does stereotyping affect its targets? In this article we describe two theories, realistic conflict theory and social identity theory, which provide an answer to the first question. We address the second question by noting that although overt discrimination has decreased, subtle forms of prejudice are still quite common and we describe one theory, aversive racism, that provides a compelling account of this change in the expression of prejudice. Finally, we answer the third question by describing two phenomena, attributional ambiguity and stereotype threat, that result from the pervasive nature of subtle stereotyping. This article is a selective overview of what social psychology has to say about these crucial issues. In addition, we review two effective intervention programs that offer promise in ameliorating the effects of stereotyping and prejudice in the classroom.

In its earliest conceptions, prejudice was treated as a manifestation of pathology (Ashmore \& Del Boca, 1981). For example, the frustration-aggression

Authors' Note: All correspondence should be addressed to Steven J. Spencer, Department of Psychology, Hope College, Holland, MI 49423. 
hypothesis (Dollard, Doob, Miller, Mowrer, \& Sears, 1939, pp. 27-54) considered prejudice to be a result of scapegoating, and authoritarian personality theory (Brown, 1965, pp. 477-546) posited that a severe childhood upbringing could result in a rigid, authoritarian adult who is prejudiced against anyone who is different from the self.

But more contemporary accounts of stereotyping and prejudice have emphasized that prejudice may be a more common and normal result of group interaction. In developing realistic group conflict theory Sherif and Sherif (1969, pp. 222-266) dismiss the notion that prejudice is pathological and suggest instead that it may frequently arise out of ordinary conflicts of interest between groups. In their studies of a boys' summer camp, they discovered that ordinary group competition for valued resources led to highly negative and stereotypical views of opposing groups and their individual members. Perhaps the more interesting aspect of these studies, however, was the manner in which conflict and hostility were ameliorated. The Sherifs found that mere contact among opposing groups only intensified the hostility (cf. Stephan, 1987). Events that required cooperative action, however, did function to reduce intergroup conflict. After several such events, all involving superordinate goals (i.e., goals shared by members of all groups), cross-group friendships began to develop and intergroup hostility began to diminish. Working cooperatively toward shared goals transformed the skills of individual group members into valued resources. So, although conflicts of interest resulted in prejudice and intense disliking between groups, action toward superordinate goals helped foster positive opinions and mutual liking.

According to another influential line of work, social identity theory (Brewer, 1979; Tajfel \& Turner, 1986), we categorize people into social groups and locate ourselves within a category. We then evaluate the value or worth of our social identities primarily by comparing our group with other groups. The basic premise of social identity theory is that we are motivated to maintain a positively valued social identity and we may do so by creating or taking advantage of favorable comparisons with other groups. The need to maintain a positive distinction between our own group and others can lead to behavior and attitudes that are biased in favor of our own group and against other groups. According to this perspective, prejudice, intergroup conflict, and stereotyping may arise simply from the struggle to attain or maintain a positive social identity (e.g., Crocker, Thompson, McGraw, \& Ingerman, 1987).

\section{DOES RACISM STILL EXIST?}

Many historical perspectives on stereotyping, including realistic group conflict theory and social identity theory, attempt to explain the prevalence of overt prejudice and discrimination. However, this kind of directly expressed racism, particularly prejudice directed toward African Americans, is becoming less common. For example, a variety of surveys that directly measure negative 
stereotypes about African Americans, attitudes toward school and residential integration, and general beliefs concerning equal opportunity all indicate that there has been a dramatic shift toward more egalitarian and less racist views over the last 50 years (see Dovidio \& Gaertner, 1991, for a review). Dovidio and Gaertner (1991) note, however, that across the variety of samples, there are still indications of overt racism in fully $20 \%$ of Whites. But what about the $80 \%$ who consistently report more positive attitudes toward African Americans?

Despite the evidence that a majority of Whites now feel generally more supportive and accepting of African Americans, there is also considerable evidence that these positive feelings may be held with some ambivalence and may mask a more subtle form of racism. For example, survey research reported in Dovidio and Gaertner (1991) indicates that although Whites seem to endorse the general idea of egalitarianism, they are opposed to specific ways in which it might be implemented, including giving preference to qualified African American job applicants and government intervention to ensure school integration. Although Whites have positive attitudes toward the abstract ideas, they also remain less than enthusiastic about personally having African American neighbors and about interracial marriage.

In addition to the survey research mentioned above, laboratory research also provides a great deal of compelling evidence demonstrating the subtle but continuing influence stereotypes have on information processing (Hamilton \& Sherman, 1994). Stereotypes make cognitive processing about our complex social worlds easier and more efficient. However, the negative consequences of this increased efficiency are reflected in the numerous studies indicating that stereotypes can significantly bias our judgments about other people (e.g., Rosenthal \& Jacobson, 1968; Sagar \& Schofield, 1980). For example, Rosenthal and Jacobson's (1968) work on teacher expectancies suggests that a priori expectations about a student's academic ability can easily lead a teacher to treat the student differentially and in accord with those expectancies (perhaps causing the student to conform to the expectancies, regardless of his or her natural ability).

Other work demonstrating the subtle yet pervasive influence of stereotypes on our everyday judgments includes a study by Banaji (1995). Students were asked to read a list of names and decide which were names of politicians and which were names of criminals. Students more often chose African-Americansounding names (e.g., Jamal Johnson) as criminals than as politicians. In another study, Devine (1989) unobtrusively led students to think about either African Americans or Whites and then asked them to read a paragraph about a man behaving in an ambiguous manner. Students who were led to think about African Americans were significantly more likely to interpret the ambiguous behavior as aggressive or hostile. Sagar and Schofield (1980) demonstrated that even schoolchildren (regardless of race) interpreted ambiguous actions as more hostile when they were committed by African Americans. We have found evidence that people may be more likely to use stereotypes after a threat to their self-esteem (Spencer, Fein, Wolfe, Hodgson, \& Dunn, 1996). This work suggests 
that, for some people, using culturally available stereotypes may be an easy way to bolster their sense of worth and adequacy.

How can this research documenting the pervasive influence of stereotypes be reconciled with the sense that most of the people we know, including ourselves, don't want to be and don't appear to be racist? One answer to this question is provided by aversive racism theory (Gaertner \& Dovidio, 1986). This theory suggests that most people consciously hold an egalitarian, nonprejudiced self-image. However, most people also have feelings, beliefs, and stereotypes that were ingrained by a racist system and are perpetuated by some aspects of contemporary culture. Caught in this bind, the theory posits that negative beliefs will have their influence when the norms guiding a situation are weak and people can easily justify their actions on the basis of some determinant other than race; that is, racism is more likely to occur in a subtle form. In this way, people can act prejudicially while still seeming to be nonprejudiced to themselves and others. For example, Dovidio and Gaertner (1983) found that Whites were more likely to accept help on a laboratory task from an African American than from a White person when the help was explicitly offered. They reasoned that refusing help from an African American might seem normatively inappropriate and racist. In another condition, however, students knew the help was available although it was not explicitly offered. In this condition, they were less likely to solicit help from African Americans than from Whites. By not requesting the help, students were able to avoid the uncomfortable situation of being subordinate to, and dependent on, an African American without violating normative guidelines or appearing overtly prejudiced to others or themselves.

All of this research suggests that, even without our conscious knowledge or intention, our evaluations and treatment of other people may be unfairly biased. There is some research suggesting that we are able to consciously correct biased judgments (Devine, 1989), but the correction process requires an awareness of the problem, as well as ample time, attention, motivation, and effort.

\section{EFFECTS OF SUBTLE STEREOTYPES ON WOMEN AND MINORITIES}

So, although overt expressions of racism and prejudice may be less prevalent, stereotypes now have a more subtle and, perhaps, more pernicious influence. What does this mean for the targets of discrimination and prejudice? (See Crocker, Major, \& Steele, in press, for a comprehensive review of the stigma literature.) One difficulty faced by stereotyped targets involves determining the motives behind outcomes and evaluations received from majority group members (Crocker \& Major, 1989). Given the subtle bias potentially present in the treatment of members of stereotyped groups, outcomes or evaluations may be accurate and deserved, but often they are biased and unfair. This leaves members of stereotyped groups in a quandary: Are these evaluations fair or are they the result of prejudice? Crocker and Major (1989) have called this phenomenon attributional ambiguity. 
In one study investigating attributional ambiguity (Crocker, Voelkl, Testa, \& Major, 1991), African American and White students were asked to write an essay and were then given either positive or negative feedback from an evaluator in an adjacent room. There was a two-way mirror between the rooms, and the blinds covering the mirror were either up or down. When the blinds were up, students could assume that their race was visible to the evaluator; however, when the blinds were down, they had no reason to believe the evaluator could identify their ethnicity. The results of the study indicated that African Americans who received negative feedback and could be seen by the evaluator were most likely to attribute the feedback to prejudice and were less likely to experience a drop in their self-esteem. When the blinds were down, however, negative feedback did lead to a drop in self-esteem. So attributing a negative outcome to prejudice did seem to protect the self-esteem of these students. An unfortunate consequence of this strategy, however, may be that positive outcomes are also questioned. Members of stereotyped groups may discount positive evaluations and successful experiences as attempts to avoid appearing prejudiced or as the result of feelings of pity. Not taking credit for success (e.g., school achievement) can lead to declines in motivation and achievement (Major \& Crocker, 1993; Major, Schmader, Spencer, Wolfe, \& Crocker, in press).

A second difficulty faced by members of some minority groups concerns the influence of stereotypes on academic performance. Some research indicates, for example, that African Americans receive lower grades than Whites at all levels of schooling (see Steele, 1992). Steele and his colleagues (Steele \& Aronson, 1995; Spencer, Carter, \& Steele, 1993; Spencer, Steele, \& Quinn, 1996) have proposed an explanation for minority underachievement in academics that emphasizes the impact negative stereotypes have on minority performance. African American students must, everyday, deal with the pervasive stereotype that they are not as intelligent and not as able to succeed as their White peers. Even if no one overtly expresses this belief, the culturally shared stereotype can undermine academic performance.

For example, Steele and Aronson (1995) found that when African American and White college students were given a difficult test of verbal ability presented as a diagnostic test of intellectual ability, African Americans performed more poorly on the test than Whites. However, in another condition, when the exact same test was presented as simply a laboratory problem-solving exercise, African Americans performed equally as well as Whites on the test. One simple adjustment to the situation (changing the description of the test) eliminated the performance differences between Whites and African Americans. Another experiment found that the test performance of African Americans dropped relative to Whites as a result of simply indicating their race on a biographical data sheet just prior to taking the test. Steele and his colleagues explain these results by noting that when a test is diagnostic and when one's race is indicated, stereotypes about African Americans could be used by others to evaluate one's performance. It is this threat, which they call stereotype threat, that they argue undermines performance. 
In a similar line of research Spencer et al. (1996) have investigated the effects of stereotype threat on women's math performance. In one study, women performed equally as well as men on a difficult test of mathematical ability when they were told that in the past there were no gender differences in performance on a given test. Women who were told there had been gender differences, however, underperformed relative to men. Again, a simple change in the situation that eliminated the stereotypical interpretation of performance eliminated a performance deficit some have interpreted as women's "inherent" inability to do high-level mathematics.

\section{CHALLENGES FOR EDUCATORS AND STUDENTS}

We can summarize the social psychological literature presented above by outlining two challenges that educators and women and minority students face in the classroom.

The first challenge is to overcome existing stereotypes potentially held by both students and teachers. Overt racist and sexist beliefs are likely to arise at some point during classroom interactions. Challenging stereotypical statements and prejudiced or racist ideology will dispel misperceptions as well as allow women and minority students to feel respected and valued. Efforts early on to establish an atmosphere in which every student feels comfortable voicing his or her opinion is an important prerequisite for discussing stereotypical beliefs and racist ideology (Schoem, Frankel, Zuniga, \& Lewis, 1993).

In addition to directly confronting stereotypes that arise, the social psychological literature suggests other ways to improve relations among students in the classroom. Sherif and Sherif's (1969) realistic conflict theory clearly demonstrates the value of superordinate goals in breaking down intergroup conflict. Aronson's jigsaw classroom (Aronson \& Gonzalez, 1988; Aronson, Stephan, Sikes, Blaney, \& Snapp, 1978) capitalizes on superordinate goals in such a way as to require student cooperation for achievement and success. Briefly, the jigsaw method of classroom instruction divides a given lesson into parts. The students are divided into multiethnic groups and each group member is given a different section of the lesson to learn. As they study their section, students are free to meet with students from other groups who have been assigned the same part of the lesson. The students in each group must then learn the entire lesson by listening carefully to individual students recite their section. This method teaches students to value what each person has to offer, reduces competition for the teacher's attention by allowing every student to feel that he or she has the "right answer," and gives students at all levels of aptitude a chance to rehearse and learn the material. Research on this technique suggests that the benefits for students in jigsaw classrooms include higher self-esteem, greater liking for school and their classmates, and improved performance on tests (see Aronson \& Gonzalez, 1988). 
When dealing with existing prejudicial beliefs, it is also important to remember the points made by social identity theory (Tajfel \& Turner, 1986). All students need to maintain a positive social identity, but creating favorable comparisons through discrimination or ingroup bias is clearly not the best means to achieve this positive identity. Engaging in educational experiences that make use of the basic principles of the jigsaw classroom (Aronson et al., 1978) and superordinate goals (Sherif $\&$ Sherif, 1969) is one way students can maintain a positive social identity while interacting cooperatively with other students. Superordinate goals do not disallow group formation or group pride, but they do encourage cooperation with, and respect for, other groups and their individual members.

A positive social identity also needs to exist in cooperation with, not in opposition to, school achievement. For some ethnic minority groups, succeeding in school is not only considered difficult, it also becomes a sign of disloyalty to one's ethnic identity. For example, African American students who succeed in school are sometimes accused of "acting White." To face this challenge, educators need to create classrooms that are relevant and accessible to all students (Schoem et al., 1993). In addition, as aversive racism theory would suggest, if educators convey strong and clear norms that racist and stereotypical views are not acceptable, then overt expression of prejudice should decrease. Therefore the classroom atmosphere needs to encourage and support different viewpoints and discussion from all students, and course content needs to integrate the contributions of women and people of color (see Bronstein \& Quina, 1988, for resources for teaching multicultural psychology). Feeling that their unique perspective is valued and learning about relevant role models can help women and minority students feel connected to education.

A second challenge for educators and students in multicultural classrooms involves the subtle influence that stereotypes can have on academic performance. Given the existence of negative and culturally shared stereotypes about intellectual ability, educators must work to minimize the conditions leading to stereotype threat (Spencer et al., 1996; Steele \& Aronson, 1995). This challenge has already been undertaken by researchers and educators at the University of Michigan. For the past several years, the university has been testing a pilot program, called The 21st Century Program, which focuses primarily on reducing stereotype threat for first-year African American students (Spencer et al., 1993). The program is based on the tenets of "wise schooling" (Steele, 1992). The major guidelines of wise schooling include racial integration, the presentation of challenges that yield personal pride, the presentation of African American historical achievement as part of the mainstream program of education, and, more generally, the treatment of students as valued human beings with talent and promise.

These tenets are realized by the 21 st Century Program in several ways. For example, both White and African American students are recruited for the program. However, given the evidence that targeting race can increase stereotype threat (Steele \& Aronson, 1995), recruitment brochures for the program make no mention of race, and all aspects of the program are explicitly presented 
as challenges, not as remedial assistance. The program involves a seminar series in which a variety of academic topics, including African American accomplishments and race relations, are covered. All of the students also participate in an accelerated workshop that emphasizes their ability to excel in one of their classes. Students are encouraged to work with others, and it is emphasized that no one person knows all the answers. All of the program participants also live together in the same dorm with the hope that they will learn to value one another as individuals.

Research on the success of the program is in its early stages, but the results suggest that it is helping. African Americans in the program maintain a higher grade average and a higher retention rate than African Americans not in the program. White program participants also show improvements in retention rates and grades, but their gains are not as substantial as those for African Americans. Although preliminary, these encouraging results are backed up by the success of similar programs implemented at various times and at various age levels (see Steele, 1992).

\section{SUMMARY}

In contrast to the early belief that prejudice was an indication of maladaptive psychological adjustment, we now know that overt prejudice may arise from everyday conflicts of interest, as well as from attempts to maintain a positive social identity. Even in the absence of overt displays of prejudice, however, recent research attests to the substantial influence that subtle racism and unexpressed stereotypes can have on judgments and academic performance. This research on stereotyping and prejudice demonstrates that minority group members are likely to face unique challenges in the classroom. These challenges can be addressed by actively respecting and valuing cultural diversity, by employing cooperative strategies such as the jigsaw classroom, and by not treating minority groups as if the stereotypes about them were true. By addressing and accepting cultural differences in our pedagogy and course content, we can create multiculturally sensitive classrooms that make education relevant and accessible to all students.

\section{APPENDIX For Further Information}

Aronson, E., \& Gonzalez, A. (1988). Desegregation, jigsaw and the Mexican-American experience. A clear and concise description of the jigsaw classroom technique for reducing overt prejudice and discrimination.

Crocker, J., Major, B., \& Steele, C. (in press). Social stigma. A lucid and thorough review of the effect of stereotyping and prejudice on the stigmatized.

Dovidio, J. F., \& Gaertner, S. L. (1991). Changes in the expression and assessment of racial prejudice. A compelling description and account of how prejudice has changed and why it takes its current form. 
Steele (1992). Race and the schooling of Black Americans. An accessible description and analysis of the problems faced in minority education.

\section{REFERENCES}

Aronson, E., \& Gonzalez, A. (1988). Desegregation, jigsaw and the Mexican-American experience. In P. Katz \& D. Taylor (Eds.), Eliminating racism (pp. 301-304). New York: Plenum.

Aronson, E., Stephan, C., Sikes, J., Blaney, N., \& Snapp, M. (1978). The jigsaw classroom. Beverly Hills, CA: Sage.

Ashmore, R. D., \& Del Boca, F. K. (1981). Conceptual approaches to stereotypes and stereotyping. In D. L. Hamilton (Ed.), Cognitive processing in stereotyping and intergroup behavior (pp. 1-35). Hillsdale, $\mathrm{NJ}$ : Lawrence Erlbaum.

Banaji, M. R. (1995, April). Automatic social categorization: New findings about stereotyping and prejudice. Paper presented at the 103rd annual meeting of the American Psychological Association, New York City.

Brewer, M. B. (1979). In-group bias in the minimal intergroup situation: A cognitive-motivational analysis. Psychological Bulletin, 86, 307-324.

Bronstein, P., \& Quina, K. (1988). Teaching a psychology of people: Resources for gender and sociocultural Awareness. Washington, DC: American Psychological Association.

Brown, R. (1965). Social psychology. New York: Free Press.

Crocker, J., \& Major, B. (1989). Social stigma and self-esteem: The self-protective properties of stigma. Psychological Review, 96, 608-630.

Crocker, J., Major, B., \& Steele, C. (in press). Social stigma. In D. Gilbert, S. T. Fiske, \& G. Lindzey (Eds.), Handbook of social psychology (4th ed.). New York: McGraw Hill.

Crocker, J., Thompson, L. J., McGraw, K. M., \& Ingerman, C. (1987). Downward comparison, prejudice, and evaluations of others: Effects of self-esteem and threat. Joumal of Personality and Social Psychology, 52, 907-916.

Crocker, J., Voelkl, K., Testa, M., \& Major, B. (1991). Social stigma: The affective consequences of attributional ambiguity. Journal of Personality and Social Psychology, 60, 218-228.

Devine, P. G. (1989). Stereotypes and prejudice: Their automatic and controlled components. Journal of Personality and Social Psychology, 56, 5-18.

Dollard, J., Doob, L. W., Miller, N. E., Mowrer, O. H., \& Sears, R. R. (1939). Frustration and aggression. New Haven, CT: Yale University Press.

Dovidio, J. F., \& Gaertner, S. L. (1983). Race, normative structure, and help-seeking. In B. M. DePaulo, A. Nadler, \& J. D. Fisher (Eds.), New directions in helping, Volume 2, Help-seeking (pp. 285-302). New York: Academic Press.

Dovidio, J. F., \& Gaertner, S. L. (1991). Changes in the expression and assessment of racial prejudice. In H. J. Knopke, R. J. Norrell, \& R. W. Rogers (Eds.), Opening doors: Perspectives on race relations in contemporary America (pp. 119-148). Tuscaloosa: The University of Alabama Press.

Gaertner, S. L., \& Dovidio, J. F. (1986). The aversive form of racism. In J. F. Dovidio \& S. L. Gaertner (Eds.), Prejudice, discrimination, and racism (pp. 61-89). Orlando, FL: Academic Press.

Hamilton, D. L., \& Sherman, J. W. (1994). Stereotypes. In R. S. Wyer \& T. K. Srull (Eds.), Handbook of social cognition (Vol. 2, 2nd ed., pp. 1-68). Hillsdale, NJ: Lawrence Erlbaum.

Major, B., \& Crocker, J. (1993). Social stigma: The consequences of attributional ambiguity. In D. M. Mackie \& D. L. Hamilton (Eds.), Affect, cognition, and stereotyping: Interactive processes in intergnoup perception (pp. 345-370). San Diego, CA: Academic Press.

Major, B., Schmader, T., Spencer, S. J., Wolfe, C. T., \& Crocker, J. (in press). Coping with negative stereotypes about intellectual performance: The role of psychological disengagement. Personality and Social Psychology Bulletin.

Rosenthal, R., \& Jacobson, L. (1968). Pygmalion in the classroom: Teacher expectation and pupils' intellectual development. New York: Holt, Rinehart \& Winston. 
Sagar, H., \& Schofield, J. W. (1980). Racial and behavioral cues in Black and White children's perceptions of ambiguously aggressive acts. Joumal of Personality and Social Psychology, 39, 590-598.

Schoem, D., Frankel, L., Zuniga, X., \& Lewis, E. A. (Eds.). (1993). Multicultural teaching in the university. Westport, CT: Praeger.

Sherif, M., \& Sherif, C. W. (1969). Social psychology. New York: Harper \& Row.

Spencer, S., Carter, K., \& Steele C. (1993, August). Increasing African-Americans' academic performance by reducing vulnerability to stereotypic evaluation. Paper presented at the $101 \mathrm{st}$ meeting of the American Psychological Association, Toronto, Ontario.

Spencer, S. J., Fein, S. J., Wolfe, C. T., Hodgson, H., \& Dunn, M. (1996). Stereotype activation under cognitive load: The moderating role of self-image threat. Manuscript submitted for publication.

Spencer, S. J., Steele, C. M., \& Quinn, D. M. (1996). Stereotype threat and women's math performance. Manuscript submitted for publication.

Steele, C. M. (1992, April). Race and the schooling of Black Americans. Atlantic Monthly, pp. 68-78.

Steele, C. M., \& Aronson, J. (1995). Stereotype threat and intellectual test performance of African-Americans. Journal of Personality and Social Psychology, 69, 797-811.

Stephan. W. G. (1987). The contact hypothesis in intergroup relations. In C. Hendrick (Ed.), Group processes in intergroup relations: Review of personality and social psychology (Vol. 9, pp. 13-40). Newbury Park, CA: Sage.

Tajfel, H., \& Turner, J. C. (1986). The social identity theory of intergroup behavior. In S. Worchel \& W. G. Austin (Eds.), Psychology of intergroup relations (2nd ed., pp. 7-24). Chicago: Nelson-Hall. 